> Norsk forskning. Tips oss hvis du er i ferd med å publisere eller nylig har publisert internasjonalt. Sakene presenteres alltid først på nett. Tips sendes til tidsskriftet@legeforeningen.no
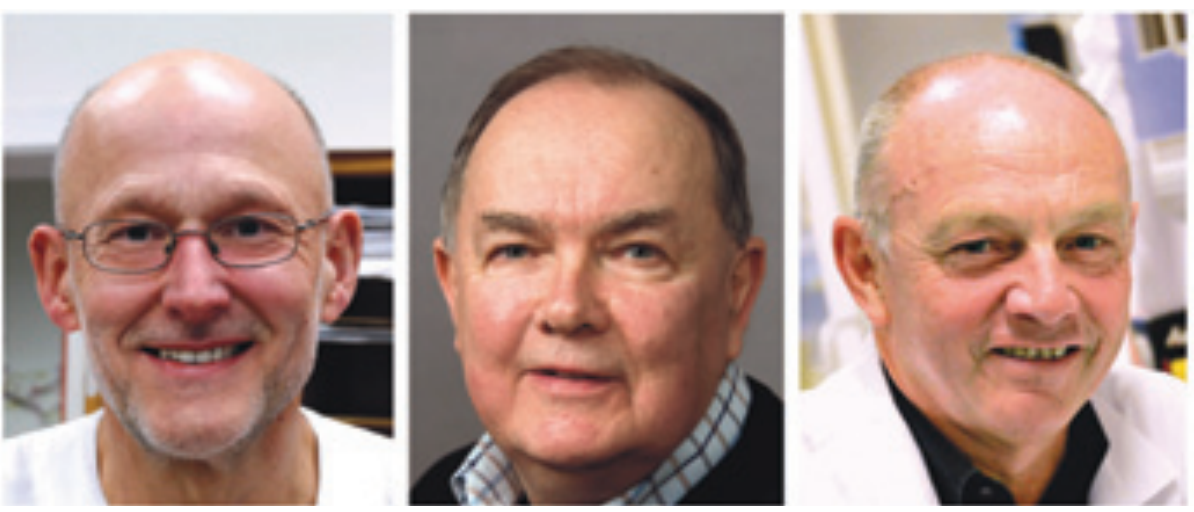

Johan G. Brun og Roland Jonsson fra Bergen og Roald Omdal fra Stavanger er tre av medforfatterne. Foto: Privat

\title{
Genvariasjoner ved Sjögrens syndrom
}

Seks gener som disponerer for utvikling av primært Sjögrens syndrom er nylig oppdaget gjennom en stor internasjonal studie.

Ved primært Sjögrens syndrom angriper immunforsvaret kroppen, spesielt spyttkjertler og tårekjertler. I tillegg til tørrhet i munn og øyne plages pasientene ofte av smerter i muskler og ledd, kronisk utmattelse og generell sykdomsfølelse. Det kan være vanskelig å stille korrekt diagnose, og det er delvis uenighet om diagnosekriteriene.

Forskere ved Stavanger universitetssjukehus og Universitetet i Bergen har sammen med en internasjonal gruppe gjennomført en studie for å påvise genetiske varianter med assosiasjon til primært $\mathrm{Sjö-}$ grens syndrom. Blodprøver fra rundt 2000 pasienter med syndromet ble testet mot prøver fra mer enn 7000 friske personer. Deltakerne ble rekruttert fra åtte forskjellige land, og blodprøvene ble analysert av forskere i hvert av landene.

Det ble funnet seks sykdomsrelaterte gener, i tillegg til HLA-gener som fra tidligere er kjent å være assosiert med primært Sjögrens syndrom. De seks «nye» genene er involvert i regulering av funksjoner i både det medfødte og det adaptive immunsystemet.

- Identifiseringen av disse genene kan bidra til å øke forståelsen av hvorfor noen mennesker utvikler primært Sjögrens syndrom, sier professor Roald Omdal ved forskningsavdelingen ved Stavanger universitetssjukehus. Sammen med fire andre norske leger er han medforfatter av artikkelen.

- Vi håper funnene kan være nyttige for videre forskning på primært Sjögrens syn- drom og andre autoimmune sykdommer. På nåværende tidspunkt finnes det kun symptomatisk behandling for Sjögrens syndrom, men med bedre kunnskaper om hvordan sykdommen oppstår, vil det kanskje bli utviklet nye behandlingsmetoder i fremtiden, sier Omdal.

\section{Internasjonalt forskningssamarbeid}

Studien er et resultat av et samarbeid mellom forskere fra Norge, Sverige, Storbritannia, Frankrike, Tyskland, Australia, Colombia og USA. Arbeidet ble ledet av forskere ved Oklahoma Medical Research Foundation i USA.

Johan G. Brun ved Revmatologisk avdeling ved Haukeland universitetssykehus og Roland Jonsson ved Broegelmanns Forskningslaboratorium ved Universitetet i Bergen er blant medforfatterne av artikkelen. Det samme gjelder Roald Omdal, Erna Harboe og Lasse Gøransson fra Klinisk immunologisk forskningsgruppe ved Stavanger universitetssjukehus. Disse forskningsgruppene har i lang tid arbeidet med epidemiologiske, kliniske, molekylære og genetiske aspekter ved flere typer autoimmune sykdommer, og spesielt med primært Sjögrens syndrom.

\section{Matilde Risopatron Berg}

Tidsskriftet

\section{Litteratur}

1. Lessard CJ, Li H, Adrianto I et al. Variants at multi ple loci implicated in both innate and adaptive immune responses are associated with Sjögren's syndrome. Nat Genet 2013; 45: 1284-92.
Ordforklaringer

HLA (human leucocyte antigens): Molekyler på overflaten av hvite blodceller som kan binde peptidfragmenter av fremmede proteiner og på denne måten gi informasjon til T-lymfocytter om farer som truer, slik at et hensiktsmessig forsvar kan iverksettes.

Multiple genvarianter: Varianter (polymorfismer) av normale enkeltgener. Selv om vi alle har de samme genene, finnes det små variasjoner av de fleste gener. Dette kan medføre en $ø k t$ eller redusert funksjon av de proteinene som genet koder for. Flere «uheldige» kombinasjoner av slike varianter av normale enkeltgener hos et individ er trolig årsak til mange sykdommer hos mennesker under gitte betingelser.

Medfødt og adaptiv immunrespons: Immunsystemet kan grovt deles i to deler - det medfødte immunsystemet, som reagerer umiddelbart når fremmede agenser, slik som bakterier og virus, kommer inn i kroppen, og det adaptive immunsystemet, som aktiveres først etter flere dager og gir danning av spesifikke antistoffer og T-celler som ødelegger det fremmede agenset - antigenet.

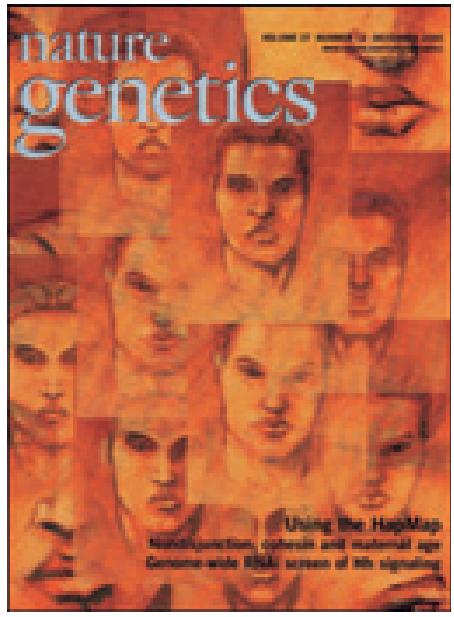

Artikkelen ble publisert 6.10. 2013 i Nature Genetics, som er et av verdens høyest rangerte vitenskapelige tidsskrifter 